\title{
Progrès dans la classification clinique de la dystrophie myotonique de type 1
}

\author{
Céline Dogan, Marie de Antonio, Dalil Hamroun, Pascale Chevalier, Malya Mati, Bruno Eymard, \\ Guillaume Bassez et le groupe d'étude français dystrophie myotonique
}

\author{
Céline Dogan \\ Pascale Chevalier \\ Malya Mati \\ Guillaume Bassez \\ Centre de Référence \\ Maladies \\ Neuromusculaires, $\mathrm{CHU}$ \\ Henri Mondor, Créteil, \\ France \\ Marie De Antonio \\ Centre de Référence \\ Maladies \\ Neuromusculaires, $\mathrm{CHU}$ \\ Henri Mondor, Créteil, \\ France \\ Inserm UMRS1138, \\ team22, Centre \\ de recherche des \\ Cordeliers, Paris, France \\ Dalil Hamroun \\ Institut Universitaire \\ de Recherche Clinique, \\ CHU de Montpellier, \\ France \\ Bruno Eymard \\ Centre de Référence \\ Maladies \\ Neuromusculaires \\ Paris-Est, CHU \\ Pitié-Salpêtrière, Paris, \\ France
}

La dystrophie myotonique de type 1 (DM1, maladie de Steinert) est considérée comme l'une des maladies génétiques les plus variables [1]. L'émergence de thérapies innovantes renforce encore la nécessité d'harmoniser, à l'échelon international, la classification clinique de la maladie [2, 10]. Malgré les initiatives de groupes de travail d'experts internationaux aucun consensus n'existe à ce jour. Plus récemment, le développement de bases de données fournit de puissants outils pour appréhender la complexité de maladies hétérogènes sur une large population. Nous nous appuyons sur les données de l'Observatoire national des dystrophies myotoniques, DMScope, pour évaluer la robustesse d'une classification de la DM1 en cinq formes cliniques, définies selon l'âge de début de la maladie. L'étude a été réalisée à partir d'une large collection de données standardisées issues de 1962 patients DM1 français adultes. Les patients ont été classés comme suit: forme congénitale (3,7\%), forme infantile $(17,8 \%)$, forme juvénile $(25,9 \%)$, forme adulte $(39,4 \%)$ et forme tardive $(13,1 \%)$. Dans un premier temps, les cinq formes cliniques ont été comparées pour la distribution de la taille de l'expansion CTG, la fréquence et l'âge d'apparition des principaux symptômes. De plus, nous avons déterminé, grâce à une méthode statistique originale combinant fréquence et temporalité, les profils d'apparition des manifestations cliniques dans chacune des formes. Les résultats ont permis de valider le modèle de classification de la DM1 en cinq groupes. Nous montrons qu'audelà du continuum, qui s'étend depuis la forme congénitale jusqu'à la forme tardive, les cinq formes cliniques se distinguent par des particularités cliniques propres. Cette étude confirme la robustesse d'un modèle de classification de la DM1 en cinq formes et met en exergue des caractéristiques cliniques spécifiques à chacune d'elles. Ces résultats devraient permettre d'optimiser le design des essais cliniques et plus particulièrement la constitution de groupes homogènes de patients.

\section{Refining myotonic dystrophy type 1 clinical classification}

Myotonic dystrophy (DM) is considered to be one of the most variable genetic diseases [1]. With the arrival of innovative DM therapies, it is becoming of crucial importance to reach harmonization on the classification of the disease [2-10]. In spite of ongoing initiatives involving working-groups of experts, no consensus is yet available. Databases are powerful tools to address the complex issue of heterogeneous diseases. Here, we assessed the robustness of a DM1 classification model divided into five clinical forms based on age of onset. The study was performed using a large collection of standardized data obtained in 1,962 French DM1 patients ( $>18$ years) from the nationwide DM-Scope registry. Patients were classified as follows: congenital (3.7\%), infantile (17.8\%), juvenile (25.9\%), adult (39.4\%) and late onset forms (13.1\%). The five clinical forms were first compared regarding the distribution of CTG expansion size and the occurrence and onset of the main symptoms. Then, using a special two-dimensional method combining time and frequency as parameters, we determined the clinical profile of the DM1 manifestations for each clinical form. Analyses validated the five-grade model of DM1 classification with regard to the triplet repeat expansion size, frequency, age of onset and clinical profiles of the main symptoms. We show that the assumption that there is a continuum from the congenital form to the late onset form is a reality. Furthermore, our data allows us to highlight clinical manifestations specific to some clinical forms.

This study provides strong evidence supporting a five-grade DM1 clinical classification model. In addition we observed specific features in clinical profiles related to particular DM1 forms. Together these results contribute to refine the DM1 classification and to improve clinical trial design, in particular enhancing the enrolment of homogeneous patients in clinical studies. 


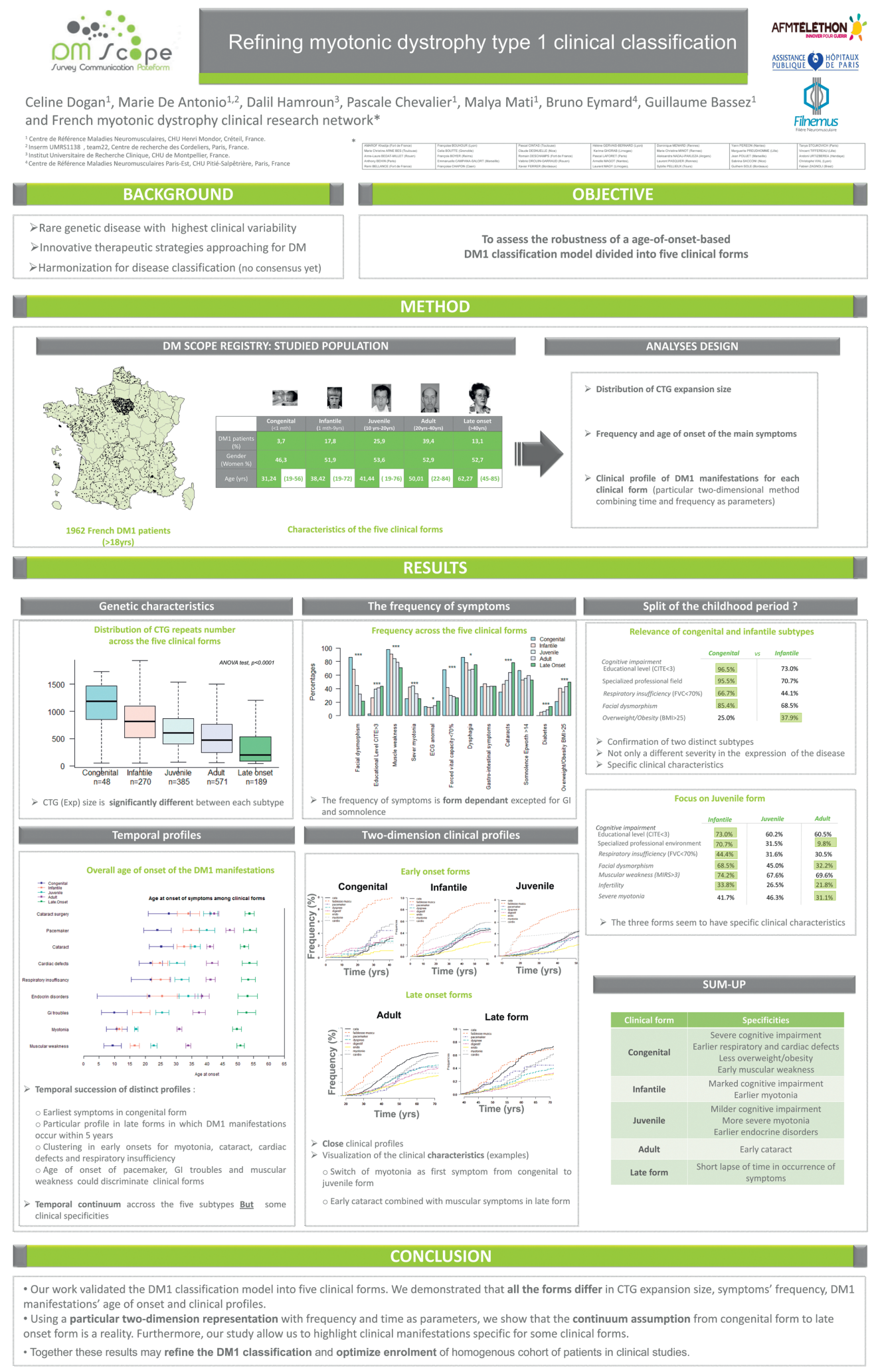

Figure 1

Contribution de l'Observatoire national des dystrophies myotoniques, DM-Scope, à la validation d'un modèle de classification de la DM1 divisé en cinq formes cliniques. 
Refining myotonic dystrophy type 1 clinical classification

\section{LIENS D'INTÉR̂̂T}

Les auteurs déclarent n'avoir aucun lien d'intérêt concernant les données publiées dans cet article.

\section{RÉFÉRENCES}

1. Harper P. Myotonic dystrophy, $3^{\text {rd }}$ ed. Major problems in neurology. London: W.B. Saunders, 2001.

2. Nakamori M, Taylor K, Mochizuki H, et al. Oral administration of erythromycin decreases RNA toxicity in myotonic dystrophy. Ann Clin Transl Neurol 2015; 3: 42-54.

3. Chau A, Kalsotra A. Developmental insights into the pathology and therapeutic strategies for DM1: back to the basics. Dev Dyn 2015 ; 244 : 377-90

4. Pandey SK, Wheeler TM, Justice SL, et al. Identification and characterization of modified antisense oligonucleotides targeting DMPK in mice and nonhuman primates for the treatment of myotonic dystrophy type 1. J Pharmacol Exp Ther 2015 ; 355 329-40.

5. Jirka S, Aartsma-Rus A. An update on RNA-targeting therapies for neuromuscular disorders. Curr Opin Neurol 2015; 28 : 515-21.

6. Klein AF, Dastidar S, Furling D, Chuah MK. Therapeutic approaches for dominant muscle diseases: highlight on myotonic dystrophy. Curr Gene Ther 2015; 15 : 329-37.

7. Bisset DR, Stepniak-Konieczna EA, Zavaljevski M, et al. Therapeutic impact of systemic AAV-mediated RNA interference in a mouse model of myotonic dystrophy. Hum Mol Genet 2015 ; 24 : 4971-83.

8. Wojtkowiak-Szlachcic A, Taylor K, Stepniak-Konieczna E et al. Short antisense-locked nucleic acids (all-LNAs) correct alternative splicing abnormalities in myotonic dystrophy. Nucleic Acids Res 2015 ; 43 : 3318-31.

9. Nguyen L, Lee J, Wong CH, Zimmerman SC. Small molecules that target the toxic RNA in myotonic dystrophy type 2. Chem Med Chem 2014 ; 9 : 2455-62.

10. Takahashi MP, Nakamori M, Mochizuki H. Therapeutic development in myotonic dystrophy. Rinsho Shinkeigaku 2014 ; 54 : 1077-9.

\section{$14^{\text {es }}$ Journées de la Société Française de Myologie 23 - 25 novembre 2016 à Bordeaux}

\section{Inscrivez-vous dès à présent aux $14^{\text {es }}$ Journées de la SFM}

\begin{tabular}{lcc|}
\hline Tarifs Net & Avant le 18 novembre 2016 & Sur place \\
Membres de la SFM* & $120 €$ & $150 €$ \\
Non membres & $250 €$ & $280 €$ \\
Formation continue & $290 €$ & $50 €$ \\
Internes / Doctorants** & $40 €$ & $50 €$ \\
Externes / Étudiants en master** & Gratuit & \\
Soirée du congrès (jeudi 24/11/2016) & $50 €$ & \\
*À jour de leurs cotisations - Sur présentation du ${ }^{\circ}{ }^{\circ}$ adhérent ** Sur présentation d'un justificatif
\end{tabular}

\section{L'appel à communication est ouvert !}

Soumettez votre projet de communication orale ou affichée.

La date limite de réception des résumés est fixée au 15 septembre 2016 minuit.

Les résultats seront disponibles au 1er octobre 2016.

Pour soumettre un projet de communication, rendez-vous sur le site du congrès

www.congres-sfmyologie.com 